\title{
THE BRITISH FOREIGN OFFICE POLICIES ON DAMAD FERID PAŞA'S PREPARATION FOR THE EXECUTION OF THE TREATY OF SEVRES
}

\author{
Dr. Neşe ÖZDEN *
}

The treaty of Sèvres, which was the peace treaty imposed by the victorious Allied powers on the Ottoman Empire after World War I, was signed with the fifth Damad Ferid Paşa government on 10 August 1920, nearly two years after the signing of the armistice of Mudros. ${ }^{1}$ Grand Vizier Damad Ferid Paşa had thrown his weight behind its signing in the hope that before ratification he could induce the Allies, the British in particular, to alleviate the harsh treaty terms and help him in overcoming both the Nationalist Movement in Anatolia and the financial difficulties of his government. ${ }^{2}$ But British political circles, both in London and İstanbul,

* Research Assistant in the History Department of the Faculty of Language and History-Geography at the University of Ankara.

1. While leaving İstanbul (Constantinople) to the Turks, the treaty of Sèvres deprived them of the Arab lands. It prescribed that the Straits were to be placed under international supervision and that Turkey was to submit her armaments to Allied control. It contemplated de jure recognition of Armenia and an autonomous Kurdistan. Eastern Thrace, the Gallipoli Peninsula, Adrianople and the majority of the Aegean islands were ceded to Greece. Smyrna was to remain under nominal Ottoman sovereignty but Greek control for five years. For a good account of the treaty of Sèvres, see D.Lloyd George, Memoirs of the Peace Conference, vol.II, New Haven 1939, pp.8624; A.Ryan, The Last of the Dragomans, London 1951, p.144; H.Nicolson, Curzon: the last phase 1919-1925, London 1937, p.252; P.C.Helmreich, From Paris to Sèvres: the partition of the Ottoman Empire at the Peace Conference of 1919-1920, Ohio 1974, chapter XIV; H.N.Howard, The Partition of Turkey: a diplomatic history 1913-1923, New York 1966, pp.242-9; M.S.Anderson, The Great Powers and the Near East 1774-1923, London 1970, pp.170-2.

2. FO371/5055/E11069/3/44 [or Documents on British Foreign Policy 19191939, (Br.Doc.), R.Butler and J.P.T.Bury (eds), First Series, vol.XIII, London 1972, pp.125-8], Robeck to Curzon, No.1191, Constantinople 23 August 1920. When the treaty of Sèvres was signed the Nationalist Movement under the leadership of Mustafa Kemal Paşa had constituted a de facto government at Ankara, deep in the interior of Anatolia, for nearly four months. The 
shared the opinion that the Turkish government could count on British support only so long as it ratified the treaty of Sèvres without delay. ${ }^{3}$ Even on the issue of the renewal of official diplomatic relations with the Turks, the British pushed the view that they could not be renewed until after the treaty of Sèvres had been ratified. ${ }^{4}$

The signing of the treaty of Sèvres encumbered the İstanbul authorities with the desperate need of justifying themselves against their critics. They were driven to issue proclamations not only to the Anatolian people but also to the leaders of Muslim countries to explain the reasons which obliged them to sign the peace treaty and the 'evils' that would result from supporting the Nationalist Movement. ${ }^{5}$ They also required the Allies to secure their ratification of the treaty before the Turks did. Damad Ferid Pasa held to the argument that if the Sultan-Caliph, Mehmed Vahideddin, were to ratify it before the Allies on their side had done anything the Sultan's position vis-à-vis his own subjects would be gravely

Ankara government declared the Sultan and his government to be a virtual prisoner of the Allies and organised opposition to the İstanbul government and resistance to the Allies and their peace terms. The finances of Damad Ferid Paşa's government were a misery. Money in hand on 31 August was about $£ 500,000$ Turkish. Monthly requirements were about $£ 1,300,000$ Turkish. Details in Br.Doc.vol.XIII (Robeck to Curzon, No.1003, Constantinople 10 September 1920), p.138; FO371/5057/E13852/3/44, Robeck to Curzon, No.1450, Constantinople 22 October 1920.

3. FO371/5055/E10860/3/44, FO to Derby (Paris), No.1002, 13 September 1920. See also E9886/3/44 (Robeck to Curzon, No.911, 12 August 1920) in Br.Doc.vol.XIII, p.123.

4. FO371/5055/E10230/3/44, Derby to Curzon, No.2675, Paris 20 August 1920. The French government contemplated that Defrance would continue to act as High Commissioner until the bringing into force of the treaty and his rank as ambassador would only become definite then. Br.Doc.vol.XIII (Henderson to Curzon, No.1033, Paris 27 August 1920), pp.128-9. Italy indicated that Signor Garroni would enter on his duties as ambassador once the treaty had been ratified. Br.Doc.vol.XIII (Buchanan to Curzon, No.363, Rome 27 August 1920), p.130. Britain, France, Italy, the United States, and Greece were each represented at Constantinople by a High Commissioner. The duties of the British High Commissioner were to maintain with the Ottoman government relations of a strictly official character with a view to the execution of the Armistice and the protection British interests, and to collaborate with the representatives of the Allied powers for the maintenance of general order and security. See Sir H. Greenwood's statement of 11 March 1920 in Parliamentary Debates (House of Commons), vol. 126, Fifth Series, 2nd Session of the 31st Parliament (From 1st March to 19th March 1920), p. 1533.

5. See, for instance, the proclamation of 1 September to be published by the Şeyhülislam in FO371/5171/E12803/262/44, Robeck to Curzon, No.1373, Constantinople 5 October 1920, weekly summary of Intelligence report for week ending 21 September. 
compromised. ${ }^{6}$ However, as far as the British were concerned it would not be possible to ratify the treaty until the British Parliament met again. ${ }^{7}$ The Foreign Office (FO) members were clever enough to get the hint from Damad Ferid Paşa that he assumed that the British would not be able to ratify the treaty until October 19 when the British Parliament reassembled. This might create an opportunity for the Ottoman government to discuss, or preferably modify, the treaty. ${ }^{8}$

For the İstanbul government, one of the complications arising out of the execution of the treaty concerned which body would ratify the treaty. According to the Turkish Constitution, the ratification of the peace treaty required the approval of the Parliament. But the Parliament had been dissolved by the Sultan on 11 April 1920 for a period of four months, ${ }^{9}$ it had not yet been recalled. Damad Ferid Paşa, therefore, came up with the suggestion that the treaty could be ratified by the Sultan alone. However, he needed British assistance to lessen the burden of such an unconstitutional act. ${ }^{10}$ The British High Commissioner in İstanbul, Admiral de Robeck, admitted that the ratification of the treaty by the Sultan, which the Grand Vizier was set on, was the only practical way to achieve ratification. Robeck also believed that Damad Ferid Paşa's government should be strongly supported in this matter, since this course was so clearly unconstitutional that no other Grand Vizier might be willing to follow it." At this point Damad Ferid Paşa occupied, in British eyes, the

6. FO371/5057/E13852/3/44, Robeck to Curzon, No.1450, Constantinople 22 October 1920.

7. O371/5055/E10230/3/44, Derby to Curzon, No.2675, Paris 20 August 1920.

8. See FO minutes in FO371/5054/E9886/3/44, Robeck to Curzon, No.911, Constantinople 12 August 1920.

9. T.Z.Tunaya, Devrim Hareketleri İçinde Atatürk ve Atatürkçülük, İstanbul 1981, p.207; Z.Sarıhan, Kurtuluş Savaşı Günlüğü, vol.II, Ankara 1984, pp.418-9. Ahmed Reşid, the Minister of Interior in the fourth Damad Ferid government, claimed that the dissolution of the Parliament was the design of Damad Ferid Paşa and Dr.Robert Frew, a Scottish priest and an Intelligence Service agent of the British High Commission in İstanbul, in order to eliminate the Parliament from the way of the execution of the treaty and thus to prepare the environment for the approval of the treaty by the Sultan alone. A.R.Rey, Gördüklerim-Yaptıklarım (1890-1922), İstanbul 1945, p.298. For Priest Frew, see S.Akşin, İstanbul Hükümetleri ve Milli Mücadele, Ankara 1974, p.131; T.Z.Tunaya, Türkiye'de Siyasal Partiler, vol.II, İstanbul 1986, p.474.

10. Reşad Halis passed the information on to Lord Derby that ratification by the Sultan might take place immediately, but he hoped the İstanbul government would receive British support in any requests that would enable them to crush the Nationalist insurrection. FO371/5055/E10230/3/44, Derby to Curzon, No.2675, Paris 20 August 1920.

11. See E9886/3/44 (Robeck to Curzon, No.911, 12 August 1920) in Br.Doc.vol.XIII, p.123. 
unique position of being the only person from whom the Allies could get the treaty ratified.

The question of making peace with Turkey had, in the Allied view, been settled with the signing of the treaty of Sèvres and now it was turn for its ratification by the Turks. The Grand Vizier aimed to ratify the treaty with the fewest disadvantages and then get Allied assistance to restore his government's prestige both in the country and in the Muslim world. At this point the main issue was to pacify Anatolia prior to the ratification. For this purpose, Damad Ferid Paşa followed two separate courses:

- peaceful means;

- forceful measures.

In the first course, he extended an amnesty to the Nationalists, except the ring-leaders of the Movement. In the second course he tried to dispose a force of repression --with British assistance-- to impose the peace treaty conditions upon the Nationalists.

This article aims to give a brief account of Damad Ferid Paşa's attempts both to eliminate the legal obstacles with respect to ratification and to crush the Nationalist Movement. It also gives special emphasis to the views of varying description (clerks, counsellors and assistant secretaries) of the FO, especially those of D.G.Osbourne, W.S.Edmonds, G.H.Fitzmaurice, J.Tilley and M.Hankey, on those attempts of Damad Ferid Paşa--as well as to the views of the British High Commission in İstanbul. ${ }^{12}$

\section{A. DAMAD FERID PAŞA'S DESIGNS TO PACIFY ANATOLIA}

12. D.G.Osbourne, W.S.Edmonds and J.Tilley, FO Eastern Department; M.Hankey, Secretary to the Cabinet, 1919-38; G.H.Fitzmaurice, Chief Dragoman in İstanbul, 1908-20, and an advisor in the FO. See D.C.Watt, Personalities and Policies: studies in the formulation of British foreign policy in the twentieth century, London 1965, pp.5-6,48; J.Tilley and S.Gaselee, The Foreign Office, London 1933; J.Connell, The Office: a study of British foreign policy and its makers 1919-1951, London 1958; M.Gilbert, Sir Horace Rumbold: portrait of a diplomat 1869-1941, London 1973, pp.71,211; M.Kent (ed.), The Great Powers and the End of the Ottoman Empire, London 1984, pp.175-6,224; Ryan, Last of the Dragomans, pp.46,86. 
The Nationalist resistance to the authority and policies of the treaty of Sèvres and the Allied pressure for its immediate application forced the İstanbul government to attempt to restore order in Anatolia. Damad Ferid Paşa on one hand proposed an amnesty which, he believed, would bring about the submission of the Nationalists with moderate tendencies to the Sultan and his government. On the other hand, he plotted against the extremists by other means. However, both courses failed. He was given no British assistance as both the British FO and the three Allied High Commissioners in İstanbul were eventually inclined to think that a mission of reconciliation to Anatolia was necessary and less risky, and would have better chances of success. The view that the İstanbul government should form a mission to send to Anatolia in order to make the Nationalists understand the treatment to which Turkey would be exposed if they persisted in resisting to the Allied terms of peace, held the day in the end.

\section{Amnesty}

Damad Ferid Paşa proposed, as a preliminary measure, to renew the offer of an amnesty, which had been published about six months earlier, to all Nationalists, except the leaders. ${ }^{13}$ His Minister of the Interior, Reşid Mümtaz Paşa, was of the opinion that the root of the unrest in Anatolia was the occupation of Turkish territory by the Greeks and that the rebel leaders had also been encouraged by foreign powers. The solution to the problem was, therefore, not a matter of internal politics so much as a movement against the terms of the peace treaty itself, and it was not within the power of the İstanbul government to satisfy the demands of the rebels. The only course to be pursued was to try once again to enlighten the Anatolian population as to the true state of affairs, and if that had no effect, to proceed to forcible measures. With regard to the question of an amnesty, Reşid Mümtaz Paşa was confident that the population generally was imbued with sentiments of loyalty but had been obliged to submit to force. The promulgation of an amnesty would therefore be both a wise and timely measure. ${ }^{14}$ Accordingly, Reşad Halis Bey, the Turkish Minister at Berne, had already pushed the view on Lord Derby, the British ambassador in Paris, that many would take the opportunity of the pardon offered by the Sultan to renew their allegiance to him, although there was a

13. The government's communiqué stated that amnesty was renewed on condition of submission within ten days. FO371/5056/E11837/3/44 (or Br.Doc.vol.XIII, pp.142-4), Robeck to Curzon, No.1050, Constantinople 23 September 1920. See also Z.Sarıhan, Kurtulus Savașı Günlüğü, vol.III, Ankara 1986 , p. 217.

14. Reşid Mümtaz Paşa's memorandum to the Sultan on 17 September in FO371/5172/E13945/262/44, Robeck to Curzon, No.1475, Constantinople 29 October 1920, summary of Intelligence report for week ending 21 October. 
large group of Nationalist leaders who would undoubtedly resist, and they were incited to do so by French financial interests. ${ }^{15}$

Damad Ferid Paşa and the Sultan hoped that the proclamation of an amnesty would divide the Nationalists and make them to submit to the central administration. The cabinet council of ministers held on 1 September was informed that a general amnesty was to be extended -upon the Sultan's desire- to all Nationalist rebels before military operations were undertaken against them. The discussions on the issue of a general amnesty, however, resulted in the resignations on 19 September of the two ministers in the cabinet: Mustafa Sabri Efendi, Şeyhülislam, and Cemal Bey, Minister of Commerce and Agriculture. Both were party men of the Moderate Entente Liberal Party, i.e., one of the two factions into which the original anti-Unionist Entente Liberal had broken after the Allied occupation of İstanbul in March $1920 .{ }^{16}$ Both ministers claimed to have abandoned Damad Ferid Paşa because of his slackness vis-á-vis the Nationalists in Anatolia. ${ }^{17}$ Upon their resignations, the Grand Vizier published a communiqué accusing the two ministers of having delayed measures to restore order in Anatolia by refusing to agree to the renewal of amnesty, which the remainder of the cabinet had agreed to. ${ }^{18}$

The two ministers' resignations due to their opposition to the proclamation of an amnesty was officially announced in the local press on 21 September. ${ }^{19}$ The FO generally regarded the resignations as opposition

15. See the conversation between Derby and Reşad Halis on 20 August in FO371/5055/E10230/3/44, Derby to Curzon, No.2675, Paris 20 August 1920.

16. FO371/5054/E9184/3/44, Robeck to Curzon, No.876, Constantinople 1 August 1920; FO371/5057/E13852/3/44, Robeck to Curzon, No.1450, Constantinople 22 October 1920. The Entente Liberal Party (ELP) served as a counter-weight to the Committee of Union and Progress (CUP) between 1911-1913 and then to the Nationalists after its reconstitution in January 1919. The ELP spawned an off-shoot, the Moderate Entente Liberal , in June 1920. Tunaya, Türkiye'de Siyasal, II, pp.271-2.

17. The alternative explanation offered by their enemies was that both ministers had been won over to Italian interests. FO371/5057/E13852/3/44, Robeck to Curzon, No.1450, Constantinople 22 October 1920; FO371/5056/E12474/3/44 (or Br.Doc.vol.XIII, pp.144-50), Robeck to Curzon, No.1349, Constantinople 28 September 1920, enclosure: Ryan's memorandum.

18. FO371/5056/E11837/3/44 (or Br.Doc.vol.XIII, pp.142-4), Robeck to Curzon, No.1050, Constantinople 23 September 1920, See also Sarıhan, Kurtuluş, III, p.214.

19. FO371/5171/E12803/262/44, Robeck to Curzon, No.1373, Constantinople 5 October 1920, weekly summary of Intelligence report for week ending 21 September. 
to a weakening of the idea of repressing the Nationalists by force. ${ }^{20}$ However, the British High Commission noticed that, whilst Cemal had always been a consistent advocate of forceful measures, there had been practically no previous indication that his opinions were shared by the Şeyhülislam, who, in fact, had on more than one occasion expressed himself as being in favour of milder measures. For instance, at the cabinet council of 7 September Cemal had openly expressed his disagreement with the proposals for an amnesty on the ground that it would be interpreted as a sign of weakness, but the Şeyhülislam had spoken in favour of the measure. His sudden change of heart might, according to the British Intelligence report, be attributed to one of those manoeuvres characteristic of the ELP. ${ }^{21}$

Damad Ferid Paşa's chances of effecting reconciliation with the Nationalists was now even more remote due to the dissension in his own cabinet. Although the cabinet accepted the amnesty unanimously, it would certainly be impossible for his cabinet, which had effected numerous Nationalist arrests and handed down many drastic sentences to persons arrested on old or very vague charges, ${ }^{22}$ to make the Nationalist leaders believe in its pretentious and insincere leniency. Damad Ferid Paşa therefore continued to stick to his forcible measures. He proposed to recruit forces from areas purged of the Nationalists and to attack from Ismid and on the Black Sea. He was sure the men could be found, but nothing could be done without Allied help, especially of a financial nature..$^{23} \mathrm{He}$ urged the view on the British that it was in the interests of the Allies, or in all events of Britain and France, to assist a government which was pledged to observe the treaty of Sèvres against a group of adventures who, if left untackled in Anatolia, would be a permanent nuisance to the British and French in the Arab countries, to the Transcaucasian states and to Persia, and would continue to receive aid from the Bolsheviks. ${ }^{24}$

20. See, for instance, Fitzmaurice's minute of 24 September in FO371/5056/E11833/3/44, Robeck to Curzon, No.1047, Constantinople 23 September 1920.

21. FO371/5171/E12803/262/44, Robeck to Curzon, No.1373, Constantinople 5 October 1920, weekly summary of Intelligence report for week ending 21 September.

22. FO371/5171/E11107/262/44, Director of MI, No.M.I.2.B., Constantinople 8 September 1920 , weekly report No.82 for week ending 18 August.

23. FO371/5171/E13451/262/44, Robeck to Curzon, No.1417, Constantinople 16 October 1920, weekly summary of Intelligence report for week ended 30 September. The Grand Vizier had in view a military force of 15,000 men rather than the gendarmerie. However, any such organisation had to come under the Inter Allied Commission contemplated in Article 200. FO371/5054/E10006/3/44, Robeck to Curzon, No.1086, Constantinople 2 August 1920.

24. Ibid. The Nationalist leaders, however divided, were all equally irreconcilable to the treaty of Sèvres and their government entered into relations with the Allies' de facto enemies, the Bolsheviks. FO371/5056/E12474/3/44 (or 
Although Damad Ferid Paşa's conviction that a show of force would be effective against the Nationalists, was not wholly dismissed by the British, the FO members felt doubtful since to recruit troops Damad Ferid Paşa had to have money, and there was no indication that he had enough. ${ }^{25}$

\section{Forcible measures}

Since the Nationalist forces had been defeated by the Greeks during the summer campaigns in western and north-western Anatolia, ${ }^{26}$ Damad Ferid Paşa hoped that they would also be defeated by his government if a punitive expedition accompanied by the Sultan were given a fair chance. ${ }^{27}$ As regards the forcible suppression of the Nationalists, he tried to effect the re-organisation of the XXVth Army Corps stationed in İstanbul. In this regard, there were two main obstacles in the way of his government. First, the İstanbul government had to be quite certain of success. Secondly, the government needed to obtain Allied permission for the conversion of the existing formations into two special compound divisions totalling 25,000 men. The government depended primarily on British assistance to get the Allied authorisation for the formation of these forces. ${ }^{28}$ The French

Br.Doc.vol.XIII, pp.144-50), Robeck to Curzon, No.1349, Constantinople 28 September 1920, enclosure: Ryan's memorandum.

25. Fitzmaurice's minute of 14 September in FO371/5055/E11336/3/44, Robeck to Curzon, No.1227, Constantinople 1 September 1920.

26. On the night of 14-15 June 1920 Nationalist forces attacked the British at Ismid and they resisted a French landing at Heraclea at about the same time. In July, however, the Greek army managed to occupy Bursa and the entire Marmora coast as far as the Ismid neutral zone. The Nationalist failure was partly due to the fact that the Greeks were given a certain amount of naval and other assistance by Britain. FO371/5057/E13852/3/44, Robeck to Curzon, No.1450, Constantinople 22 October 1920. In June 1920 the British Prime Minister gave further aid and encouragement to the Greeks at the Hythe conference, when Eleutherios Venizelos, the Greek Prime Minister, offered an army of 90,000 men with which to destroy the Nationalists. In spite of Italian, rather than French, opposition at this juncture, Venizelos continued to have the loyal backing of the British government at Boulogne and Spa. H.H.Cumming, Franco-British Rivalry in the Post-War Near East: the decline of French influence, New York 1981, pp.126-7. See also B.C.Busch, Mudros to Lausanne: Britain's frontier in West Asia, 1918-1923, New York 1976, pp.222-33; Ryan, Last of the Dragomans, p.145.

27. The general policy of his government was outlined by Damad Ferid Paşa to a British journalist on 24 September 1920. FO371/5171/E13451/262/44, Robeck to Curzon, No.1417, Constantinople 16 October 1920, weekly summary of Intelligence report for week ended 30 September.

28. FO371/5171/E11107/262/44, Director of MI, No.M.I.2.B., Constantinople 8 September 1920 , weekly report No.82 for week ending 18 August; FO371/5171/E11717/262/44, Director of MI, No.M.I.2.B., Constantinople 21 September 1920, weekly report No.83 for week ending 25 August. 
Premier was not really enthusiastic about the project of raising forces. British Foreign Minister Lord Curzon, on the other hand, had no objection to the Grand Vizier's raising the forces at his disposal to 15,000 men with the authorisation of the inter-Allied military commanders --provided the latter were satisfied that these forces would not join the Nationalists. However, he objected to the infringement of the treaty involved in acceding to the Turkish request to raise a force of two divisions totalling $25,000.29$

Immediately after the resignation of the two ministers in his cabinet the Grand Vizier addressed a long note to the High Commissioners in which he asked for a loan of £T.20,000,000, and outlined military proposals for an offensive against the Nationalists. ${ }^{30}$ Damad Ferid Paşa's proposals of a military and financial nature asserted:--

(a). 15,000 troops and 25,000 gendarmes to be recruited in small areas under effective authority of the government and areas occupied by the Greek vendettas ceded to them;

(b). Guns and material held by the Allies since the armistice of Mudros, signed on 30 October 1918, to be placed at the disposal of the government;

(c). Naval convoys for transports carrying government troops;

(d). Military foreign officers for gendarmerie and other services, as contemplated in the treaty;

(e). Loan by the Allies of $£ T \cdot 25,000,000$, being estimated cost of three months' operations with a margin for unforeseen expenses. ${ }^{31}$

The Grand Vizier's proposals were received by Robeck on 20 September. Robeck then exchanged views with General Wilson, the General Officer Commanding-in-Chief of the Army of the Black Sea, and asked the following questions:

29. FO371/5054/E10018/3/44, WO to FO, No.0152/5477(M.I.2), 17 August 1920 and its enclosure: FO to WO, 27 August 1920; FO371/5055/E10185/3/44, Cambon (French Charge d'Affairs) to Curzon, 20 August 1920, enclosure: Curzon to de Fleuriau, 27 August 1920; Br.Doc.vol.XIII (Curzon to Robeck, No.880, 23 September 1920), p.144. Tilley supported the French opinion. FO371/5057/E7442/3/44, From French Ambassador, 29 June 1920, enclosure.

30. FO371/5056/E12474/3/44 (or Br.Doc.vol.XIII, pp.144-50), Robeck to Curzon, No.1349, Constantinople 28 September 1920, enclosure: Ryan's memorandum.

31. FO371/5056/E11837/3/44 (or Br.Doc.vol.XIII, pp.142-4), Robeck to Curzon, No.1050, Constantinople 23 September 1920. 
(a). Was it possible for the İstanbul government, without assistance from the Allies in money and the loan of Allied officers, to organise a military force capable of overcoming the Nationalist forces?

(b). Was the Grand Vizier's estimate of $£$ T.20,000,000 sufficient?

(c). Was the Grand Vizier's estimate of only three month's operations justifiable in view of the necessity of recruiting and training the 15,000 men?

(d). What would happen if the forces of 15,000 men went over whole or in the part to the side of the Nationalists? ${ }^{32}$

In reply, Wilson expressed his opinion that the organisation of the forces would take at least 6 months, but that if they were properly handled there would be little danger of their going over to the Nationalists. To Wilson, a properly organised government force would probably find little difficulty in defeating the Nationalist armies, provided the Bolsheviks did not give considerable active and material assistance. ${ }^{33}$

In the FO, Edmonds was of the belief that the danger seemed to be not so much that individual members of the force would desert to Mustafa Kemal, but rather that a Turkish government of Nationalist tendencies might allow the force to be used for purposes which the Allies could not approve. ${ }^{34}$ Osbourne was of the opinion that a well-armed Turkish force could suppress the Nationalist Movement unless considerable assistance were to be supplied by the Bolsheviks. But the ultimate disposal of the Turkish Armenian vilayets (cities) might be a difficult issue, as the Allies could not foresee how Turkish troops would fight for the dismemberment of their country. ${ }^{35}$ Fitzmaurice urged the necessity for the British to act in harmony, especially with the French, in giving moral and material assistance to the İstanbul government to carry out the treaty. Fitzmaurice believed that the Greeks only wanted the treaty executed and presumably would be delighted to see the Sultan's government do so, or to keep it with supplies to achieve that object. ${ }^{36}$ Hankey and Tilley advocated that the Allies should consult Venizelos about getting the treaty executed with the help of raising forces against the Nationalists. ${ }^{37}$

32. FO371/5056/E13138/3/44, Robeck to Curzon, No.1394, Constantinople 9 October 1920, enclosure: High Commissioner to Wilson, Constantinople 28 September 1920.

33. Ibid, enclosure: Wilson to High Commissioner, Constantinople 5 October 1920.

34. Edmonds' minute of 26 October in ibid.

35. Osbourne's minute of 27 October in ibid.

36. Fitzmaurice's minute of 18 August in FO371/5054/E10018/3/44, WO to FO, No.0152/5477(M.I.2), 17 August 1920.

37. Tilley's minute of 18 August in ibid. Hankey's minute in FO371/5054/E10018/3/44, WO to FO, No.0152/5477(M.I.2), 17 August 1920. 
The War Office (WO) had no objection, from the military point of view, to permission being granted to the İstanbul government to raise two divisions, totalling 25,000 men for repression of the Nationalist Movement, though this would constitute an infringement of the peace terms. In the army council's point of view, the peace terms could be enforced in Anatolia much more easily by the Istanbul government than by an Allied force, though the Greeks might not be favourable to such an arrangement. ${ }^{38}$

The Grand Vizier's note sounded like a formal call upon the Allies to support the İstanbul government in every way, if they wanted it to execute their treaty. ${ }^{39}$ But the High Commissioners agreed on 21 September that the note was not in the last degree practical. They leaned towards the idea of a mission of pacification to Ankara instead. But the Grand Vizier, when verbally approached on the subject by French High Commissioner Defrance, expressed his doubt as to the success of a purely Turkish mission. The High Commissioners were indecisive on this point. ${ }^{40}$

By the mid-autumn of 1920 , the punitive expedition against the Nationalists could not get beyond the paper stage and it remained doubtful whether such an expedition would ever proceed to Anatolia. ${ }^{41}$ Damad Ferid Paşa's inability in handling the chaos in Anatolia and the financial crisis made his government's already difficult position completely untenable. The number of persons who took the view that Damad Ferid Paşa should be got rid of at once, or else induced to ratify the treaty quickly and then made to give way to a modest person, such as ex-Grand Viziers Tevfik Paşa or Marshal İzzet Paşa, was on the increase in British political circles. ${ }^{42}$

\section{B. QUESTION OF MEDIATION BETWEEN ISTANBUL AND ANKARA}

38. FO371/5054/E10018/3/44, WO to FO, No.0152/5477(M.I.2), 17 August 1920.

39. FO371/5056/E12474/3/44 (or Br.Doc.vol.XIII, pp.144-50), Robeck to Curzon, No.1349, Constantinople 28 September 1920, enclosure: Ryan's memorandum.

40. FO371/5056/E11837/3/44 (or Br.Doc.vol.XIII, pp.142-4), Robeck to Curzon, No.1050, Constantinople 23 September 1920.

41. FO371/5171/E12227/262/44, Robeck to Curzon, No.1288, Constantinople 14 September 1920, Intelligence report for week ended 2 September.

42. FO371/5055/E11247/3/44 (or Br.Doc.vol.XIII, pp.139-40), Robeck to Curzon, No.1004, Constantinople 10 September 1920. Robeck was hopelessly forced to think that even a Grand Vizier who had French support might receive the financial assistance required from the Ottoman Bank under a French government guarantee. 
Following the Greek campaigns in the summer of 1920, the Allied High Commissioners had agreed in principle to give support for a mission of pacification since they considered that a further Greek advance into Anatolia would endanger the treaty by intensifying the anti-Greek feeling of the Anatolian people which had already reached a dangerous point since the Greek occupation of Smyrna on 15 May 1919.43 Assuming that Mustafa Kemal's military position was desperate and that Mustafa Kemal was in fear of the exiled Unionist leader Enver Paşa's replacing him, the FO members, too, leaned towards the alternative of detaching him and his more moderate adherents from the extremists who were prepared to sacrifice Turkey to the Enver-Bolshevik ambitions. ${ }^{44}$ However, it took quite a long time to reach a consensus among the Allies on the nature of the mission to be sent to Ankara.

Meanwhile, complications increased due to the government's impotence to take active measures against the Nationalists, as well as the actions of the Greek authorities in the occupied territories. ${ }^{45}$ Officers and men for the projected punitive expedition to Anatolia had not come forward in adequate numbers. It seemed that the only way to avoid the new dangers would be a radical change in the administration. ${ }^{46}$ Eventually, the High Commissioners gave more thought to have Damad Ferid Paşa succeeded by Tevfik Paşa. The removal of Damad Ferid Paşa was strongly emphasised by Defrance. Robeck was reluctantly falling in line with Defrance's position. Italian High Commissioner Arlotta was hesitant to

43. See the Allied High Commissioners meeting of 29 July 1920 in FO371/5054/E10006/3/44, Robeck to Curzon, No.1086, Constantinople 2 August 1920.

44. Osbourne's minute of 4 October in FO371/5056/E12184/3/44, Robeck to Curzon, No.1065, Constantinople 1 October 1920. In British eyes, the Nationalists were divided principally under three distinct parties: the antiBolsheviks, animated by the traditional Turkish fear of Russia, the Unionist wing, which favoured the acceptance of Bolshevism; and Mustafa Kemal's faction, who feared complete surrender would become necessary unless they obtained outside help, and was unwillingly inclining to get into line especially with the exiled wartime leader Enver Paşa who had been involved in plots --together with the Soviets-- against the Allies since his escape abroad in November 1918. CAB24/115, C.P.2192, No.24, 'A monthly review of revolutionary movements', October 1920. Pan-Islamist and, especially, Pan-Turkist ideas took hold of Enver Paşa and in the post-war situation he expected the Turkic areas of Central Asia to play a vital role in the struggle against the Allies and the Christian communities. E.J.Zürcher, Turkey: a modern history, New York 1995, pp.140-1.

45. FO371/5171/E12472/262/44, Robeck to Curzon, No.1347, Constantinople 28 September 1920, Intelligence report summary for week ended 9 September.

46. FO371/5171/E12473/262/44, Robeck to Curzon, No.1348, Constantinople 27 September 1920, Intelligence report summary for week ended 16 September. 
proceed without definite authority from his government. ${ }^{47}$ His hesitancy might also be due to the dilemma that while the Italian representatives already passed the information to the İstanbul government that Italy was in favour of sending a mission of pacification to the Nationalists to put an end to the chaotic state of affairs in Turkey and to maintain friendly relations with the Caliphate, ${ }^{48}$ the Italian government had actually no determined view as to the efficacy and scope of a mission to Anatolia yet.

\section{Despatch of a Mission of Reconciliation to Anatolia}

Throughout the months following the signing of the treaty of Sèvres, the contrasting expectations and methods of British and French policies, as well as those of Italy and Greece, over the Turkish question had still not ceased. Nor was the further use of Greek armed forces practicable. The British felt that the Allies had now been left with principally three options. They could either take an active hand in attempting to unify Turkey, they could maintain the existing Ottoman government or they could change it. ${ }^{49}$

British politicians and diplomats were cautious about further straining British prestige in the Muslim world as well as providing any kind of support, including money and officers, to the İstanbul government. Nor, unless circumstances forced them to, did the British wish to destroy the basis of the existing treaty by further utilising the Greeks and the additional need to compensate them which this would entail. On the other hand, Defrance, who believed that Damad Ferid Paşa's personality was one of the greatest obstacles to the union between İstanbul and Ankara, suggested that Damad Ferid Paşa must go. Defrance was lukewarm about any form of negotiations with the Nationalist leaders themselves, and equally lukewarm about boldly using the only threat which the Allies could use, that of a further Greek advance which he described as the Allies' only potential weapon. While Defrance demurred at the idea of giving the mission the character of formal negotiations with the Nationalist leaders, Arlotta was personally of the opinion that, should a mission be sent to Anatolia, it would stand a better chance of success if composed of, or at

47. FO371/5056/E12183/3/44 (or Br.Doc.vol.XIII, pp.152-3), Robeck to Curzon, No.1064, Constantinople 1 October 1920.

48. See, for instance, Reşid Mümtaz Paşa's account of his interview with the Italian Minister at Lucerne in FO371/5171/E12227/262/44, Robeck to Curzon, No.1288, Constantinople 14 September 1920, Intelligence report for week ended 2 September.

49. FO371/5056/E12474/3/44 (or Br.Doc.vol.XIII, pp.144-50), Robeck to Curzon, No.1349, Constantinople 28 September 1920, enclosure: Ryan's memorandum. 
least accompanied by, Allied delegates. Robeck was slow to fall in with Defrance's suggestion because he was very uncertain how far the Allies could trust any government which the Allies might bring into power to uphold the treaty without playing into the hands of the Nationalists. No Turkish government, Robeck felt, could live on the threats of further punishment alone. However, if events of themselves forced Damad Ferid Paşa to resign Robeck would not particularly regret it as there was uneasiness in Allied circles that the British were keeping him in office for their own ends. ${ }^{50}$

The Italian note of 10 September proposed that instead of a purely Turkish mission, either an Allied mission should be despatched, or the Turkish mission should be accompanied by representatives of the Allies. ${ }^{51}$ The draft French reply of 20 September to the Italian note accepted the principle of a mission, but stated that if despatched by an Istanbul government, like the one represent by Damad Ferid Paşa, it might meet with a rebuff likely to endanger any chance of a compromise. The French put forward the view that in order to promote the success of the mission, it should not be composed of, or at least accompanied by, Allied representatives. The French government desired the British government to work to bring about the formation of a new Turkish cabinet to supervise the constitution of the Anatolian mission and the means of meeting the financial requirements of the government. ${ }^{52}$

Opinion at the $\mathrm{FO}$ as regards the method of securing ratification and the role of Damad Ferid Paşa in it varied. The head of foreign affairs, Lord Curzon, was resolute that delay in the ratification of the treaty was a primary cause of continued dissension in Turkey. If Damad Ferid Paşa refused to ratify the treaty, it would then be time to find a successor who would be more amenable. ${ }^{33}$ The FO agreed in principle with the French to

50. For the Allied High Commissioners' opinion, see ibid; FO371/5055/E11247/3/44 (or Br.Doc.vol.XIII, pp.139-40), Robeck to Curzon, No.1004, Constantinople 10 September 1920; FO371/5056/E11833/3/44, Robeck to Curzon, No.1047, Constantinople 23 September 1920; FO371/5056/E11837/3/44 (or Br.Doc.vol.XIII, pp.142-4), Robeck to Curzon, No.1050, Constantinople 23 September 1920; FO371/5056/E11862/3/44, Robeck to Curzon, No.1058, Constantinople 25 September 1920.

51. FO371/5055/E11658/3/44, Derby to Curzon, No.2965, Paris 20 September 1920. See also FO371/5055/E11596/3/44, Imperiali to Curzon, No.1921, London (Italian Embassy), 17 September 1920,

52. See enclosure and also Fitzmaurice's minute of 21 September in ibid.

53. Ibid, enclosure: Curzon to Derby (Paris), 1 October 1920. See also FO371/5055/E11596/3/44, Imperiali to Curzon, No.1921, London (Italian Embassy), 17 September 1920, enclosure: Curzon to Imperiali, 1 October 1920. 
send a mission of appeasement to Mustafa Kemal. The most important object for the British to secure, however, was still the ratification of the treaty by the existing Turkish government. The French opinion that Damad Ferid Paşa was the obstacle to ratification and reconciliation with the Ankara government, was found by Osbourne to be 'dubious' as regards the first. Osbourne believed that reconciliation with the Nationalists and the establishment of some form of united government was the primary necessity, but this might entail a delay in the ratification. No new government could approach Mustafa Kemal if at the same time they were ratifying the treaty. In Osbourne's belief, Mustafa Kemal should be convinced of the necessity for ratification, and acceptance of the treaty by a new representative Chamber should be carried out, even though it might be a further cause of delay. Osbourne suggested that Damad Ferid Paşa should be induced to ratify the treaty at once and then disappear and leave it to a successor to appease the Nationalists. The danger of this, however, would be that the treaty would have been accepted by one government and might be repudiated by a future representative government. Osbourne regretted that the British could not invite Mustafa Kemal himself from Ankara to İstanbul. ${ }^{54}$ Fitzmaurice shared similar views to those of Robeck that it was difficult to find any successor to Damad Ferid Paşa who would or could ratify the treaty without revision, especially in the matters of Smyrna and Thrace. ${ }^{55}$ Fitzmaurice had no objection to sending a mission to Anatolia accompanied by Allied representatives, provided such arrangements were made as to reasonably exclude the likelihood of their being kidnapped by the Nationalist forces. ${ }^{56}$ Hankey believed that after the İstanbul government ratified the treaty, the Allies could immediately afterwards go to the formation of a new government to get into touch with Mustafa Kemal and to secure the pacification of Anatolia. But, if the İstanbul government refused to ratify the treaty, the Allies must then find a government that would. In Hankey's opinion, the mistake in sending a mission to Anatolia before ratification would be 'inadmissible', since it would open the door to bargaining with Mustafa Kemal who would probably make his agreement to ratification conditional upon modifications of the treaty. ${ }^{57}$

An important phase of discussions at the FO on the issues of the mission of reconciliation to Anatolia and Damad Ferid Paşa's elimination was opened with the memorandum of 23 September written by Andrew Ryan, the Chief Dragoman of the British High Commission. In his memorandum, Ryan came to the crux of the whole matter by asking the

54. Osbourne's minute of 21 September in ibid.

55. Fitzmaurice's minute of 13 September in FO371/5055/E11247/3/44, Robeck to Curzon, No.1004, Constantinople 10 September 1920.

56. Fitzmaurice's minute of 20 September in FO371/5055/E11596/3/44, Imperiali to Curzon, No.1921, London (Italian Embassy), 17 September 1920.

57. Hankey's minute in FO371/5055/E11658/3/44, Derby to Curzon, No.2965, Paris 20 September 1920. 
question of whether the British government wanted the treaty to stand or not. If the British government did not, he saw no better course than to let the situation rip and go from bad to worse. This was, according to Ryan, a 'gloomy prospect'. Even the Greeks could not overrun the whole of Anatolia, and beyond the limits of effective occupation the Nationalist Movement must either remain as an organised force or dissolve and leave behind it widespread disorder as well as a very poor government in İstanbul. Ryan, therefore, saw no hope except in artificially strengthening the İstanbul government by giving it strong Allied support, including financial help in some shape, if the British wanted the treaty to stand. In Ryan's opinion, no Turkish mission, whether sent by Damad Ferid Paşa or anyone else, was likely to effect anything unless it was amenable to the Nationalist wishes, i.e., modification of the treaty. ${ }^{58}$ Ryan was quite successful in foreseeing the future developments, if the treaty were to stand as it was. However, he could not see the inevitable end that it was beyond reality for the İstanbul government to be revived, even with vast Allied assistance.

While Ryan's suggestions were about to be discussed at the FO, Venizelos addressed a letter to the British Prime Minister on the subject of a further Greek advance into Anatolia. ${ }^{59}$ Venizelos' telegram of 5 October to Lloyd George stated that the İstanbul government would be unable to reduce Mustafa Kemal and that it would be extremely dangerous to grant the permission requested by them to form new divisions, for these would fatally reinforce the Nationalists. The only radical remedy, according to Venizelos, would be a new campaign supported by Allied funds with the object of destroying the Nationalist forces around Ankara and the Pontus. Venizelos ended by appealing for a very prompt decision, since in a few weeks' time the winter season would set in and make a campaign almost impossible. ${ }^{60}$ But the British administration did not regard his proposals as applicable since it seemed unlikely that the Greeks could manage a campaign before winter set in. It was of the opinion that Venizelos' proposals amounted to tearing up the Turkish treaty and they were not likely to be at all acceptable to the French and Italian governments. ${ }^{61}$

Upon the receipt of Venizelos' letter of 5 October, the FO members mixed their discussions on Ryan's memorandum with the issue of a

58. FO371/5056/E12474/3/44 (or Br.Doq.vol.XIII, pp.144-50), Robeck to Curzon, No.1349, Constantinople 28 September 1920, enclosure: Ryan's memorandum.

59. Osbourne's minute of 13 October in FO371/5056/E12474/3/44, Robeck to Curzon, No.1349, Constantinople 28 September 1920.

60. Br.Doc.vol.XIII (Venizelos to Lloyd George, Athens 5 October 1920), pp.157-8. See also M.L.Smith, Ionian Vision: Greece in Asia Minor 19191922, London 1973, pp.131-2.

61. CAB23/22, C.54/(20), 'Conclusions of a Meeting of the Cabinet, held on 12 October 1920'. 
possible Greek advance into Anatolia. Osbourne was of the opinion that, assuming that Venizelos did not demand too high a price or one entailing a modification of the treaty to the detriment of Turkey (which Osbourne thought the Allies should never agree to) and that the Allied military authorities were satisfied that the Greeks could perform the task quickly and decisively, a Greek advance into Anatolia might offer the best solution in spite of its inherent disadvantages. However, he drew attention to the danger that a new Greek advance might determine Mustafa Kemal and the now hesitating moderate element to join Kazım Karabekir Paşa ${ }^{62}$ and threw their lot in with the Bolsheviks. It might seriously endanger both the position of Venizelos in the event of military failure as well as that of the Christians in the areas controlled by the Nationalists. It might also have disastrous effects for prestige of the İstanbul government and in İstanbul itself. Also, a further Greek advance and a possible modification of the treaty in favour of Greece would almost certainly mean a rupture with Italy over the Allies' Turkish policy since both Italy and Greece claimed the same areas in south-western Anatolia. Osbourne, therefore, came to the conclusion that whatever decision might be taken, the mission to Anatolia should be tried first. Mustafa Kemal might even be told that the only alternative to his acceptance of the treaty and assistance in the pacification of Anatolia would be further Greek operations. Thereafter, whatever the result, Osbourne thought the British should, as Ryan and Robeck suggested, assist the Turks to restore order in their own house rather than risk the doubtful alternative of further military operations which would be likely to increase the existing chaos and to revive Nationalist resistance. ${ }^{63}$ Osbourne advised waiting for the reply from the High Commissioner to the FO's suggestion that a meeting should be arranged between a British officer and Kazım Karabekir Paşa with a view to opening the way to a possible understanding with the moderate Nationalists. ${ }^{64}$ Edmonds believed that the success or failure of the despatch of a Turkish mission to the provinces depended on the prestige of the İstanbul government, and to deal with Mustafa Kemal would only result in restoring his prestige. But, if existing efforts to provide the Turks with funds and forces succeeded, the prestige of the İstanbul government might become considerable. If

62. On 10 August, the Bolsheviks invaded Armenia. On September 20 Kazım Karabekir Paşa, the commander of the XVth Army Corps, co-operating from the west, occupied Kars and Ardahan. Nicolson, Curzon, p.259. The signing of the peace between Russian Armenia and the Bolshevik forces in Transcaucasia might greatly facilitate communications between the Bolsheviks and the XVth Army Corps, and might make possible the supply of fresh armaments and funds to the Nationalist army. FO371/5171/E11107/262/44, Director of MI, No.M.I.2.B., Constantinople 8 September 1920 , weekly report No.82 for week ending 18 August.

63. Osbourne's minute of 13 October in FO371/5056/E12474/3/44, Robeck to Curzon, No.1349, Constantinople 28 September 1920.

64. Osbourne's minute of 25 September in FO371/5056/E11837/3/44, Robeck to Curzon, No.1050, Constantinople 23 September 1920. 
officers and officials were regularly paid, if a start were made by restoring a tolerable administration in districts near İstanbul which had been suffering from 'Nationalist terrorism', the moderate Nationalists would have some reason to think that the best policy was to transfer their allegiance from Mustafa Kemal to the Sultan. ${ }^{65}$ Tilley, on the other hand, gave a cold shoulder to Ryan's memorandum which, he said, did not impress him very much. Tilley was very determined that the treaty must not be altered or risked for anything. Tilley pointed out that, even without offering more to the Greeks, a fresh Greek advance could be carried out and would not have disastrous results. ${ }^{66}$

The British High Commissioner agreed with Ryan's memorandum in general. Robeck was of the opinion that, however small the chances of terminating the existing state of affairs in Anatolia and securing acceptance of the peace treaty by purely pacific means might be, an attempt to do so should be made. In forming this opinion, Robeck was greatly influenced by the consideration that it would be impossible for the İstanbul government to organise such a force in a short period of time and that without the Allied support, including considerable financial aid, it would be entirely fruitless. ${ }^{67}$

Meanwhile, the Allied High Commissioners' meeting on 24 September paved the way for the elimination of Damad Ferid Paşa from the list of people who could possibly achieve ratification by pacific means. At the meeting all were agreed that any mission to Anatolia should be sent by the Sultan and his government. Defrance considered that it should be accompanied by a certain show of force, and should proceed gradually from district to district rallying the moderate Nationalists to the Sultan. Robeck objected that this would be very slow and even disastrous if the Bolsheviks were able (e.g., as a result of peace with Poland) to give effective support to the Nationalists. The other two High Commissioners eventually concurred with Robeck's position of urging the immediate despatch by the Sultan of a Turkish mission accompanied by representatives of the High Commissioners. In the end, it was decided that the Grand Vizier should be informed on the whole subject. ${ }^{68}$ The FO members were divided as to whether the mission should be accompanied by Allied representatives. Osbourne were not sure whether it was wise to allow Allied representatives to accompany the mission. ${ }^{69}$ Hankey was sure

65. Edmonds' minute of 12 October in FO371/5056/E12474/3/44, Robeck to Curzon, No.1349, Constantinople 28 September 1920.

66. Tilley's minute in ibid.

67. Ibid, enclosure: Robeck to Curzon, Constantinople 28 September 1920.

68. FO371/5056/E11862/3/44, Robeck to Curzon, No.1058, Constantinople 25 September 1920.

69. Osbourne's minute of 27 September in ibid. 
of the advantages of the mission being accompanied by the Allied representatives; he would not trust a purely Turkish mission. ${ }^{70}$

The situation in İstanbul developed, after Ryan's memorandum had been written, on lines unfavourable to the project of despatching a mission to Anatolia by the existing Turkish government. When the political officers of the Allied High Commissions verbally approached him on 25 September, Damad Ferid Paşa took a more uncompromising line than he had done before. He told them that conciliatory methods could not usefully be employed to produce a settlement in Anatolia unless the organisation of repressive forces was proceeded with concurrently, the mission was accompanied by Allied representatives and the Allies had no truck with the Nationalist leaders whom the İstanbul government had denounced as rebels. ${ }^{71}$ Damad Ferid Paşa was of the opinion that if by accepting the demands of the Nationalists the country's interests would be served, the cabinet would immediately withdraw, but this was not the case. He was prepared to agree to a reconciliation with the Nationalist leaders themselves if they did not oppose the application of the peace treaty and submitted unreservedly to the İstanbul government. His government had decided not to send any official mission whatsoever to negotiate with the Nationalists, who were not in the least likely to accept such conditions; their attack upon Armenia in conjunction with the Bolsheviks further proved their intention of persisting in their uncompromising attitude. ${ }^{72}$ In short, Damad Ferid Paşa's priority was to obtain Allied backing in restoring order, but, in fact, there was no hope for this assistance.

\section{Necessity for the Elimination of Damad Ferid Pasa}

Both the Sultan and his Grand Vizier were worried about the possibility of advent to power of a government of a Nationalist complexion and pressed on the British the idea that any moderate-serving cabinet which might now take power would be a merely a stepping-stone to a government of a definitely Nationalist complexion which would certainly

70. Hankey's minute in ibid.

71. FO371/5056/E12474/3/44, Robeck to Curzon, No.1349, Constantinople 28 September 1920, enclosure: Robeck to Curzon, Constantinople 28 September 1920. Damad Ferid Paşa called on Robeck on 27 September and reaffirmed his obstinate attitude. FO371/5056/E12183/3/44 (or Br.Doc.vol.XIII, pp.152-3), Robeck to Curzon, No.1064, Constantinople 1 October 1920.

72. See Damad Ferid Paşa's memorandum of 8 October to the Sultan in FO371/5172/E13945/262/44, Robeck to Curzon, No.1475, Constantinople 29 October 1920, summary of Intelligence report for week ending 21 October. Damad Ferid Paşa had no intention of sending either an official or semi-official mission to negotiate with the Nationalists. Such action, he considered, would not be in keeping with the dignity of his government. FO371/5172/E14131/262/44, Director of Military Intelligence, No.M.I.2.B., 11 November 1920 , Constantinople weekly report No.90 for week ending 13 October. 
oppose acquiescence to the treaty. ${ }^{73}$ Damad Ferid Paşa even hinted to Robeck that the Sultan was reaching his limits of endurance and might abdicate rather than consent to work with a government of Nationalist character. ${ }^{74}$ In other words, Damad Ferid Paşa's only weapon against the British seemed to be the threat of the Sultan's abdication. However, it was a weapon which could easily be turned against him.

Upon the Grand Vizier's intimidation and the apparent possibility of the Sultan's abdication, the FO was resolute that they could not dare to sacrifice the Sultan, but they could sacrifice Damad Ferid Paşa. Osbourne did not think the British could refuse to help the Sultan to leave Turkey, but the Sultan should be urged not to abdicate. ${ }^{75}$ Edmonds believed that if the High Commissioners managed it, the French would have no further ground to refuse to collaborate in the İstanbul government's raising forces, and the Nationalists might in fact feel rather more inclined to accept the Sultan's authority. ${ }^{76}$

The High Commissioners finally decided at the meeting on 7 October to proceed at once with written a communication to the İstanbul government recommending the despatch of a mission to Anatolia. ${ }^{77}$ They also committed themselves to promise to send delegates. ${ }^{78}$ Just before this meeting, a new element was introduced into the situation by a message from the Sultan asking the High Commissioners to visit him. The High Commissioners accepted the Sultan's offer on the condition that the audiences should be strictly private, which implied that the Grand Vizier should not be present. The High Commissioners' joint note recommending the despatch of a mission as a purely pacific experiment, and without limitation as to the persons with whom it should enter into relations, was handed to Damad Ferid Paşa on the same day and the reply concerning the interviews was conveyed simultaneously. ${ }^{79}$

73. See FO371/5056/E12184/3/44 (or Br.Doc.vol.XIII, pp.151-2), Robeck to Curzon, No.1065, Constantinople 1 October 1920; FO371/5056/E13038/3/44, Robeck to Curzon, No.1408, Constantinople 14 October 1920.

74. FO371/5056/E12215/3/44 (or Br.Doc.vol.XIII, pp.154-5), Robeck to Curzon, (secret and personal), Constantinople 4 October 1920.

75. Osbourne's minute of 5 October in ibid.

76. Edmonds' minute of 4 October in FO371/5056/E12184/3/44, Robeck to Curzon, No.1065, Constantinople 1 October 1920.

77. FO371/5056/E12658/3/44, Robeck to Curzon, No.1100, Constantinople 13 October 1920.

78. FO371/5056/E12832/3/44, Robeck to Curzon, No.1104, Constantinople 14 October 1920.

79. FO371/5056/E12658/3/44, Robeck to Curzon, No.1100, Constantinople 13 October 1920. 
The High Commissioners' interviews with the Sultan took place on 11 October and were actually final talks with the Sultan for assessing his reaction to the possibility of Damad Ferid Paşa's removal. During the interview the Sultan was very insistent that the mission should be sent to demand submission, not to listen to conditions. He wanted to know what was to happen if the overtures to the Nationalists were unsuccessful. ${ }^{80}$ Referring to the High Commissioners' joint note presented to the Grand Vizier on 7 October, the Sultan expressed gratification at the willingness of the High Commissioners to attach delegates of their own to the mission. He promised to give the mission his full support, but observed pointedly that such support could be moral only and not material. According to Robeck, in saying so the Sultan had meant that it would have been better to adopt the plan of combining conciliation with a display of force in dealing with the Nationalists. The Sultan made a strong appeal for military assistance from the Allies via Britain, whom he described as the only country for his country to stand by. As regards the ratification of the treaty, he feared that if Turkey were to take the lead in ratifying the treaty, the reaction to his cabinet would be great. The Sultan also said that the only neutral people in Turkey were the people who were capable of nothing. ${ }^{81}$ The Sultan's statements impressed Edmonds, who found the friendly disposition on the part of the Sultan towards Britain to be in a large measure genuine. Edmonds believed that the Sultan's remark that the only neutral people were those capable of nothing was only too true. The great difficulty of creating a moderate government in Turkey was that the moderate Turks did not count. ${ }^{82}$ Osbourne realised that the Sultan wanted a mission of coercion with a stick in its hand rather than one of pacification with a white flag. But the only existing available stick was the Greek army and that cost too much. In Osbourne's belief, the Allies might perhaps wave it without having any intention of using it. ${ }^{83}$ Tilley supported the Sultan's specific urging that the mission to the Nationalists should be told to make no concessions. ${ }^{84}$

Meanwhile, Robeck received a letter from Defrance, on 14 October, transmitting the French government's latest instructions which suggested financial assistance to the İstanbul government, the immediate raising of the 15,000 men as contemplated in the treaty with the necessary precautions against desertions, and the installation of the International commissions immediately after the ratification. The French urged that the British should accept the Turkish ratification by the Sultan and Ministry

80. Ibid.

81. FO371/5056/E13038/3/44, Robeck to Curzon, No.1408, Constantinople 14 October 1920.

82. Edmonds' minute of 23 October in ibid.

83. Osbourne's minute of 23 October in ibid.

84. Tilley's minute of 23 October in ibid. 
but not the Parliament. ${ }^{85}$ This latest French programme represented not so much the agreed programme of the Allies as the French government's conception of the logical results of their exchange of views. ${ }^{86}$

Robeck was opposed to the French programme. His objections were due to the possible risk that if the Sultan was tried too far he might abdicate, and the French proposals would increase the chance of it greatly. If the Sultan abdicated the Allies would have in the existing Heir Apparent Abdülmecid a 'successor' who was notoriously hostile to the treaty. Robeck saw that a ministry composed of puppets of the High Commissioners would certainly possess no authority, and unless the British were prepared to take over the government themselves, the outcome would be either a government of extreme anti-Nationalist or, much more probable, a government of definite Nationalist sympathies with whom neither the British nor the Sultan would work. ${ }^{87}$ According to Robeck, the chances of the proposed mission's success would be much diminished by the refusal to send Allied delegates. In any case, he restated, the High Commissioners had already committed themselves to promise to send delegates. ${ }^{88}$ Robeck then put forward an alternative policy, which propounded to:

(a). Proceed with the mission on the lines agreed to between the High Commissioners;

(b). Continue to urge on the İstanbul government immediate ratification, but refrain from exerting strong pressure, at least until the Allied ratifications were definitely in sight;

(c). Make no attempt to keep Damad Ferid Paşa in power or to drive him from power;

(d). Dissuade the Sultan from regarding his personal position as bound up in that of any particular ministry;

(e). Prepare quite definitely for the contingency of the failure of mission;

85. FO371/5056/E12741/3/44, Robeck to Curzon, No.1103, Constantinople 14 October 1920. The French proposals also suggested the resignation of the existing cabinet after the ratification of treaty; the subsequent formation of a new ministry of persons selected by the High Commissioners; and an Anatolian mission sent by new government and composed of persons selected, but not accompanied, by the Allied High Commissioners.

86. Ibid.

87. FO371/5056/E12832/3/44, Robeck to Curzon, No.1104, Constantinople 14 October 1920.

88. Ibid. 
(f). Proceed with the constitution of financial and military commissions without delay and without awaiting the ratification of the treaty, even by Turkey. ${ }^{89}$

The London-based foreign-policy makers, on the other hand, generally concurred with the French programme, except that they could not commit themselves to financial help. Osbourne was inclined to think the French were right in objecting to the mission being accompanied by the Allied representatives, in case of a rebuff. ${ }^{90}$ Osbourne did not think Robeck's objections to the French programme would stand against its obvious advantages and he thought the mission to the Nationalists would have much greater chances of success after the ratification of the treaty and after a change of ministry. ${ }^{91} \mathrm{He}$ regarded the French desire of avoiding any risk of a rebuff as 'sound'. According to Osbourne, it also accorded with the High Commissioner's principle to avoid interference in Turkish domestic concerns. ${ }^{92}$ Tilley was suspicious about the France's speaking of financial avances to the Istanbul government. He could not understand what the French contemplated when they spoke of avances, since there was no chance of financial backing from the British and anyone else. ${ }^{93}$ Hankey noticed that the French had decided on pressure being put upon the İstanbul government to ratify, and on the despatch of a mission, but without foreign interference in it. ${ }^{94}$ In Hankey's opinion, the British should insist on the ratification of the treaty by the Istanbul government and the acceptance of the proposal that the ratification by the Sultan and his government would suffice. When ratification took place the British could then decide upon the further steps to be taken, but the British might give the impression of general agreement with the views of the French government. ${ }^{95}$

Neither the British nor the French, Curzon imagined, would press for immediate ratification if it really entailed abdication of the Sultan. The British government would have preferred not to send a representative with the mission in order not to be associated with a possible rebuff, but if the British High Commission were committed to this point the FO would leave

89. FO371/5056/E12833/3/44, Robeck to Curzon, No.1105, Constantinople 14 October 1920.

90. Osbourne's minute of 14 October in FO371/5056/E12575/3/44, French Embassy (communicated by), 12 October 1920.

91. Osbourne's minute of 18 October in FO371/5056/E12741/3/44, Robeck to Curzon, No.1103, Constantinople 14 October 1920.

92. Osbourne's minute of 19 October in ibid.

93. Tilley's minute of 14 October in FO371/5056/E12575/3/44, French Embassy (communicated by), 12 October 1920.

94. Hankey's minute in FO371/5056/E12658/3/44, Robeck to Curzon, No.1100, Constantinople 13 October 1920.

95. Hankey's minute in FO371/5056/E12575/3/44, French Embassy (communicated by), 12 October 1920. 
it to the decision of Robeck and his colleagues. Curzon hoped to ratify in London early in the existing session, and asked Robeck to use this as an argument with the İstanbul government. ${ }^{96}$ But there was no time left to communicate with the İstanbul authorities. Damad Ferid Paşa saw that he was held up to contempt for abdicating his cabinet's functions. $\mathrm{He}$ therefore preferred to leave the reply to the High Commissioners' note to his successor and resigned on 16 October. The Sultan offered the Grand Vizierate to Tevfik Paşa..

Damad Ferid Paşa's resignation was mostly the result of his hesitation to come to terms with the Nationalists, as well as that of his hesitation in view of the fact that the ratification would further weaken the İstanbul government vis-à-vis Anatolia, as the government would present the appearance of not merely having submitted to the treaty but of having welcomed it. ${ }^{98}$ In his endeavours, Damad Ferid Paşa made three principal errors. Firstly, the integrity of his policies was vague and inconsistent. Yet his artificial leniency towards the Nationalists deceived only himself. When his policy seemed merciful towards the insurrectionists in Anatolia, he was accused of slackness, yet when it was stern he was accused of over-severity. ${ }^{99}$ Secondly, Damad Ferid Paşa was too illusory in expecting that the British would, financially and materially, support the İstanbul government for halting the Nationalists and for overcoming its own financial difficulties. Moreover, as Tilley said, the administration of Turkey was to be so tied up with the foreign control commissions that it was difficult for the British to give special help, especially in view of the French and Italian spheres in Anatolia. ${ }^{100}$ Lastly, it was mistake of Damad Ferid Paşa to imagine that the Nationalist Turks would agree drain the Sèvres cup simply on account of a request by the İstanbul government. ${ }^{101}$

Damad Ferid Paşa's elimination came as a necessary condition of the pacification of Anatolia. The French High Commissioner had always been resolute that Damad Ferid Paşa's resignation would remove the last restraints upon the conclusion of the Turkish peace treaty. Although the

96. FO371/5056/E12741/3/44, Robeck to Curzon, No.1103, Constantinople 14 October 1920, enclosure: Curzon to Robeck, 23 October 1920.

97. FO371/5056/E13012/3/44, Robeck to Curzon, No.1120, Constantinople 19 October 1920.

98. FO371/5056/E12658/3/44, Robeck to Curzon, No.1100, Constantinople 13 October 1920.

99. FO371/5055/E11336/3/44, Robeck to Curzon, No.1227, Constantinople 1 September 1920.

100. Tilley's minute of 8 September in FO371/5055/E11069/3/44, Robeck to Curzon, No.1191, Constantinople 23 August 1920.

101. See the remark of the correspondent of the Bosphore newspaper in FO371/5172/E13945/262/44, Robeck to Curzon, No.1475, Constantinople 29 October 1920, summary of Intelligence report for week ending 21 October. 
British, up to the last moment, resisted Defrance's suggestion for the removal of Damad Ferid Paşa from power, when it appeared to be inevitable the British High Commissioner bowed to the inevitable. ${ }^{102}$ As Osbourne said, Defrance thus got his way concerning the replacement of Damad Ferid Paşa. ${ }^{103}$ According to Osbourne, Damad Ferid Paşa's resignation 'fortunately' dispensed the British from interfering in Turkish politics. He also hoped that it would also deter the Sultan from abdication, a step which the British were strongly urging him not to contemplate. ${ }^{104}$ Osbourne believed that the British must now try and get the new ministry to ratify at once and then set up the various commissions. ${ }^{105}$ Similarly, Tilley was glad that Damad Ferid Paşa's resignation simplified British discussions with the French. ${ }^{106}$

\section{CONCLUSION}

Initially, the FO members had strongly believed that the primary requirement to solve the Turkish question was the ratification itself. For instance, Osbourne thought the mission to Ankara would have much greater chances of success after the ratification of the treaty. In Hankey's opinion, too, it was a great error to send a mission into Anatolia before ratification, since it would mean the bargaining with the Nationalist leader. Instead of dealing with Mustafa Kemal, Edmonds advised furnishing the İstanbul government's force with Allied funds and forces. However, the FO experts soon realised that it had been an illusion to hope that ratification would clear the ground for the pacification of Anatolia. They eventually admitted that an understanding with the Nationalists was the primary requirement before the ratification. The British FO, before applying to pacific solutions, considered principally two alternatives:

- enabling the İstanbul Government to restore order in Anatolia by giving it financial and material assistance; or

- direct action by the Allied powers or, preferably, the Greeks.

As regards the first alternative, the FO members, especially Edmonds and Osbourne, had initially held hopes that a trained Turkish force could possibly suppress the Nationalist Movement. Edmonds feared, however, that if a government with strong Nationalist leanings were to come to power, it might allow these forces to be used for Nationalist ends. The

102. FO371/5057/E13852/3/44, Robeck to Curzon, No.1450, Constantinople 22 October 1920.

103. Osbourne's minute of 4 October in FO371/5056/E12184/3/44, Robeck to Curzon, No.1065, Constantinople 1 October 1920.

104. Osbourne's minute of 19 October in FO371/5056/E12741/3/44, Robeck to Curzon, No.1103, Constantinople 14 October 1920.

105. Osbourne's minute of 18 October in ibid.

106. Tilley's minute of 18 October in ibid. 
British were concerned about what would happen if the forces which Damad Ferid Paşa desired to raise proved untrustworthy. Although the İstanbul government had claimed that with the organisation of a force it could itself re-establish its authority and thus carry on with the ratification process, it was obvious that this would require time and money. The British FO thus favoured that no permission to raise such forces should be granted until after the ratification of the Turkish peace.

As regards the second alternative, the Allies were unable to undertake a joint campaign in Anatolia due to a variety of reasons. For one, Britain's allies, France and Italy, were no longer solid with the Allied companionship. As the British observed, the French had been divided into two camps, according to whether they desired to see a restored, though reduced, Turkey, or to deprive the Turks of the power to hurt them in Syria, Cilicia and Heraclea. ${ }^{107}$ The French, with Nationalist aid, hoped to carry through a policy of economic and cultural penetration even though they knew that the Nationalist Movement was irreconcilable to their pretensions in Syria and the future French zone of influence. ${ }^{108}$ The Italians became rather the supporters of Nationalist Turkey in the struggle against an Anglo-Franco-Hellenic peace. ${ }^{109}$ In other words, a joint Allied military intervention in Anatolia would not tolerate any breach in the alliance but there was no solid union on the part of the Allies.

Since there was almost no hope for the application of direct action by the Allied powers, the only available force in Allied hands seemed to be the further employment of the Greek forces. However, a new Greek advance into Anatolia could be realised only if:

- the Greeks would not require fresh compensation in return. Otherwise, this would mean a break over Turkish policy with the other Allies.

- it was certain of success. Otherwise, any military failure by Greek forces would seriously endanger the position of Venizelos in Greece. ${ }^{110}$

107. FO371/5056/E12474/3/44 (or Br.Doc.vol.XIII, pp.144-50), Robeck to Curzon, No.1349, Constantinople 28 September 1920, enclosure: Ryan's memorandum.

108. FO371/5057/E13852/3/44, Robeck to Curzon, No.1450, Constantinople 22 October 1920.

109. Ibid. Due to the possible expansion of Greece, Italy was forced to pursue a policy of continual watchfulness and was prepared to give Turkey all assistance, morally and materially. FO371/5171/E12227/262/44, Robeck to Curzon, No.1288, Constantinople 14 September 1920, Intelligence report for week ended 2 September.

110. As Lord Curzon foresaw, the weakening of the position of Venizelos and the return to power of King Constantine would mean a reversal of the existing cordial Allied policy towards Greece. Nicolson, Curzon, p.257. 
- it would not determine the Nationalists to further engage with the Bolsheviks, or, to oppress the Christians in the regions under Nationalist control.

- it would not have disastrous effects on the position and prestige of the Sultan-Caliph and his administration-- as well as in Istanbul itself.

Moreover, there appeared a great scepticism among the British foreign policy departments as to the application of pro-Greek policies. Lloyd George, whose sympathy towards Venizelos never cooled, generated the pro-Greek solutions to prevent the treaty of Sèvres from being overthrown by the Nationalists. He believed that, in return for territorial advantages in Anatolia, the Greeks could assume the chief burden of enforcing the Sèvres provisions upon the Nationalist government."'1 Besides him, Arthur James Balfour, Lord President of the Council, and Harold Nicolson, British diplomat and writer, were on the pro-Greek side. Opposed to the Greek ambitions in Anatolia were Edwin Montagu, the Secretary of State for India, as well as Winston Churchill, the Secretary of State for War, and the General Staff under its Chief, Henry Wilson. They drew some support from the British Foreign Minister: Lord Curzon, though holding the view that the British ought to dismantle the Ottoman Empire and deprive the Turks of control of İstanbul and the Straits, advocated that Anatolia should not be divided among the Allies and Greece. Permanent Under-Secretary Lord Hardinge approved Curzon's view. ${ }^{112}$ The scepticism expressed by Montagu, Churchill, Wilson and Hardinge was shared by some inside the FO. But in many occasions they were unable to stop Lloyd George, who centralised a great part of British foreign policy-making mechanism in his own hands and deliberately ignored the FO and neighbouring departments when it suited him to do so. ${ }^{113}$

111. G.A.Craig, "The British Foreign Office from Grey to Austen Chamberlain", The Diplomats 1919-1939, Princeton 1994, p.34; Lloyd George, Memoirs, II, p.867.

112. For details, see N.Petsalis-Diomidis, Greece At the Paris Peace Conference (1919), Thessaloniki 1978, p.176-7; E.Maisel, The Foreign Office and Foreign Policy, 1919-1926, Brighton 1994, pp.36,44,53; Watt,

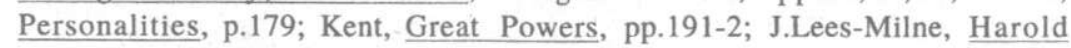
Nicolson: a biography 1886-1929, London 1980, pp.154-5; J.Darwin, Britain, Egypt and the Middle East Imperial Policy in the Aftermath of War 1918-1922, London 1981, pp.14-23.

113. For details, see Maisel, Foreign Office, pp.62-8; Watt, Personalities, p.178; B.C.Busch, Hardinge of Penshurst: a study in the old diplomacy, Hamden 1980, p.294; K.O.Morgan, "David Lloyd George", in British Prime Ministers in the Twentieth Century, (ed.by J.P.Mackintosh), vol.I, London 1979, pp.137-8. 
By the mid-autumn of 1920 , there was still no real solution in the question of peace with Turkey. The British military authorities were constantly warning that if the period between signing and ratification were prolonged, the Allied presence in İstanbul might be at stake. ${ }^{114}$ The FO members thus came to waive the alternative of a further application of the Greek army and to favour a smoother course, e.g. the method of conciliation, instead. As Robeck reported, the contention of the advocates of the method of conciliation was such that: having regard to the exhausted state of the Anatolian population, the dissension among the Nationalist leaders, and Mustafa Kemal's failure to contest the latest Greek advance, there was at least a hope that the situation might be represented to the bulk of the rebels in such a light as to rally them round the Sultan's government on the basis of acquiescence in the treaty. ${ }^{115}$

The FO members, who always urged the view that the Sultan or his ministry had to ratify the treaty since the Ottoman Empire was the one who had been defeated in the War, finally agreed that the Allies should urge sending a mission to the Nationalists (the French said 'without', the High Commissioner said 'with' Allied officers), but certainly not drive the Sultan to abdicate. ${ }^{116}$ They, though in agreement with the necessity of a mission of pacification to Anatolia, had still different views on the issue of whether the Allies should accompany the mission or not. While Osbourne supported the French objections to the mission being accompanied by Allied representatives in case of a rebuff, Hankey and Fitzmaurice regarded the mission being accompanied by Allied representatives as advantageous.

In conclusion, it may be said that Damad Ferid Paşa's priorities were the suppression of the Nationalist Movement and the relief of his government's financial difficulties. But the FO saw them as a matter of secondary importance in comparison to the matter of ratification. While the British High Commissioner clearly warned the FO that even if Damad Ferid Paşa ratified the treaty his extreme unpopularity might handicap him so greatly as to make his retention in office impossible, neither the FO nor the British High Commission could stop themselves from regarding Damad Ferid Paşa to be the only Grand Vizier for the execution of the treaty of Sèvres. ${ }^{117}$ However, even if they had not regarded him so and

114. See General Milne(Commander-in-Chief of British troops in Turkey)'s warnings in FO371/5054/E10006/3/44, Robeck to Curzon, No.1086, Constantinople 2 August 1920.

115. FO371/5057/E13852/3/44, Robeck to Curzon, No.1450, Constantinople 22 October 1920.

116. Tilley's minute of 19 October in FO371/5056/E12741/3/44, Robeck to Curzon, No.1103, Constantinople 14 October 1920.

117. FO371/5054/E9184/3/44, Robeck to Curzon, No.876, Constantinople 1 August 1920. See also E9886/3/44 (Robeck to Curzon, No.911, 12 August 1920) in Br.Doc.vol.XIII, p.123. 
they had brought to power a modest Grand Vizier much earlier, it was almost certain, as Osbourne drew attention to, that no new Grand Vizier could solve the Anatolian enigma if at the same time Turkey was forced to a reluctant peace.

\section{Makalenin Türkçe özeti}

\section{SEVR BARIŞ ANTLAŞMASI'NIN YÜRÜRLÜḠE GIRMESI ICÇINN DAMAD FERID PAŞA'NIN HAZIRLADIḠI PLANLARA YÖNELIIK İNGILIZZ POLITTIKASI}

I. Dünya Savaşı'nın mağlupları arasında yer alan Osmanlı İmparatorluğu'nun İtilaf devletleri ile yapması beklenilen barıs antlaşması -yaklaşık iki yıllık bir gecikmeyle- 10 Ağustos 1920'de Sevr'de imzalandı. Ancak ağır barış koşullarını içeren bu antlaşma, imzalanmasının ötesinde bir yol katedememiş ve onaylanmadı ̆̆ 1 için de yürürlüğe girmeyen ölü bir antlaşma olarak tarihe geçmiştir. Makale, Sevr'in onaylanması ve Milli Mücadelecilerin bertaraf edilmesi için Sadrazam Damad Ferid Paşa'nın geliştirdiği politikalardan örnekler vermeyi ve İngiliz dış politikası açısından bunların nasıl değerlendirildiğini yansıtmayı amaçlamaktadır. Damad Ferid Paşa'nın bu planlarına yönelik İngiliz dış politikası incelenirken, özellikle İngiliz Dışişleri Bakanlığı belgelerindeki dış politika uzmanlarının yorumları (FO minutes )'ndan faydalanılmıştır.

Sevr Barış Antlaşması'nın imzalanmasını müteakiben gerek Beşinci Damad Ferid Paşa hükümeti, gerekse Ankara'da Milli Mücadelecilerce yaklaşık dört ay önce kurulmuş olan Ankara hükümeti farklı yöntemlerle bu antlaşmaya karşı politikalar geliştirmişlerdir. Sevr Antlaşması'nı şiddetle reddeden Milli Mücadeleciler bu antlaşmayı imzalayan Istanbul hükümetine karşı tepkilerini yoğunlaştırırken, Damad Ferid Paşa'nın İtilaf devletlerine karşı koz olarak kullandığı barış antlaşmasını 'onaylama' formülünde ise Sevr'in kabulünün kaçınılmazlığı gibi sabit bir fikrin 
yanısıra barış şartlarının kısmen de olsa yumuşatılabileceği beklentisi vard. Bu amaçla hem Sultan hem de Damad Ferid Paşa, çeşitli bahaneler yaratarak zaman kazanmaya çalıştılar. Örneğin İngilizlerden, antlaşmayı kendilerinden önce onaylamalarını istediler. Bu talebin altında yatan başlıca neden, İngilizlerin 19 Ekim'den önce Parlamentolarını toplayıp, bu onaya imza atamayacakları gerçeğiydi. Böylece onay tarihi, en az iki ay ertelenebilecekti.

Damad Ferid Paşa, İtilaf devletlerine Sevr'i yürürlüğe koyacağı sözünü vermek ve İngilizlerle işbirliği yapmak suretiyle, hükümetinin finansal zorluklarını ve Milli Mücadelecilerin gụ̧̈lenen varlığını bertaraf etmeyi amaçlamaktaydı. Damad Ferid Paşa'nın Ittilaf devletlerine sürekli olarak empoze etmeye çalıştığı fikre göre, Sevr Antlaşması'nın onaylanarak yürürlüğe girmesini engelleyen en büyük etken, Milli Mücadelecilerin tepkisi idi. Böylece, Damad Ferid Paşa Sevr'i onaylamadan önce hükümetinin varlığını tehdit edebilecek güçte olduğunu hissettiği Milli Mücadelecileri İtilaf devletlerinin, özellikle de İngilizlerin, desteği ile ortadan kaldırmayı umuyordu. Bu arada İtilaf devletlerine, Sevr'in onaylanmasına istekli olduğu yolunda sinyalleri vermeyi de ihmal etmedi.

Damad Ferid Paşa, Milli Mücadelecilere yönelik olarak birbirinden çok farklı olan iki yöntem izlemiştir:

Birincisi , Sultan-Halifeye hâlâ bağlı olan Milli Mücadelecileri tekrar merkezî hükümetin saflarına dahil edecek ve onları Sevr'in onaylanmasının gerekliliği konusunda ikna edecek girişimlerde bulunmak.

Íkincisi ise , askerî güç kullanarak Milli Mücadelecileri Sevr'i kabule zorlamak.

Birinci yöntemle ilgili olarak Damad Ferid Paşa hükümeti, Milli Mücadelecilere (liderleri hariç olmak şartıyla) yönelik genel af tasarısını Sultan'ın önerisi çerçevesinde gündeme getirdi. Damad Ferid Paşa hükümetinin temsilcileri ve dış ülkelerdeki Osmanlı diplomatları (ör. İçişleri Bakanı Reșid Mümtaz Paşa ve Bern'deki Osmanlı elçisi Reşad Halis Bey) İngiliz temsilcileriyle yaptıkları ikili görüşmelerde, Anadolu'daki isyancı oluşumun kaynağını Türk topraklarının Yunanlılar tarafından işgal edilmesine ve bazı dış güçlerin kışkırtmalarına (ör. Bolşevik Rusya) veya ikili oynamalarına (ör. Fransa) dayandırmaktaydılar. Problemin sadece Osmanlı yönetimini ilgilendirmediğine ve uluslararası ilişkileri de etkileyen bir boyutu olduğuna dikkat çekerek, bu isyancı hareketi engellemenin ve böylece de barış antlaşmasına giden yolun açılmasının ancak İtilaf devletlerinin desteği ile mümkün olabileceğini iddia etmekteydiler. Sultan ve Damad Ferid Paşa ise, genel af sayesinde Anadolu halkının olayın iç yüzünü (!) 
anlayacağına ve Sultan'a olan bağlılıklarını göstereceğine inanmaktaydılar. Ancak çok geçmeden anlaşıldı ki, Damad Ferid Paşa'nın fikirleri kabinedeki bazı bakanlarca paylaşılmıyordu. Milli Mücadelecilere yönelik af programı, hükümet içindeki kimi bakanlar tarafından zayıflık alameti olarak görüldü̈ğünden, istifalarına neden oldu. 19 Eylül'de Şeyhülislam Mustafa Sabri Efendi ve Ticaret ve Tarım Bakanı Cemal Bey istifa etti. Bu bakanların Mutedil Hürriyet ve Itilaf Partisi 'nin üyeleri olmaları, istifaların önemini daha da arttırdı. Çünkü genel olarak siyasi çevrelerin ve Anadolu halkının tepkisini çeken Damad Ferid Paşa, şimdi de yegâne destekçilerinden olan Mutedil Hürriyet İtilafçıları kaybetmeye başlamıştı.

İkinci yöntemle ilgili olarak Damad Ferid Paşa, askerî tedbirlerle Milli Mücadelecileri bastırabilmek için, hükümet denetimindeki mevcut kuvvetleri yeniden organize ederek güçlendirmeyi planladi. Fakat, İstanbul hükümetinin elindeki maddi olanakların yetersizliği, önündeki en büyük engeldi. Dahası, İtilaf devletlerinin de iznini gerektiren bu tür girişimlerden önce, özellikle İngiliz (Fransızların olumsuz tavır sergilemesi nedeniyle) desteğinin alınması şarttı. Bunun için de, Sevr'in onaylanmasını sağlamak suretiyle İngilizleri memnun etmek zorunda olduğunun farkındaydı. Ancak, Damad Ferid Paşa hükümetinin Sevr'i onaylamadan önce çözmesi gereken önemli bir sorun vardı: 'antlaşmayı onaylayacak makamı' tesbit etmek. Anayasa'ya göre, barış antlaşmasının yürürlüğe girmesi için Parlamento'nun onayı gerekliydi. Fakat Parlamento, Sultan tarafından 11 Nisan 1920 'de 4 aylık bir süre için kapatılmıştı ve yakın bir tarihte açılması da pek muhtemel görünmüyordu. Damad Ferid Paşa'nın bu soruna yönelik çözümü ise, barış antlaşmasının "direkt olarak Sultan'ın onayı" ile yürürlüğe girmesi yönündeydi. Belki de, Damad Ferid Paşa'nın bir önceki hükümetinde İçişleri Bakanı olan Ahmed Reşid (Rey) Bey'in anılarında iddia ettiği gibi, Parlamento Nisan ayında 'kasıtlı' olarak kapatılmış ve böylece parlamentosuz bir ortamda sadece Sultan'ın onaylayacağı bir barış antlaşması için gerekli altyapı aylar öncesinden hazırlanmıştı. Bu iddianın doğruluğunun tartışılmasından ziyade, burada vurgulanması gereken nokta, Damad Ferid Paşa'nın --kasıtlı olarak ya da

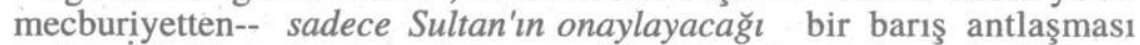
teziyle İtilaf kanadına hoş görünme çabası içine girmiş olmasıdır. Damad Ferid Paşa'nın anayasaya böylesine aykırı düşen bir tezi uygulamaya koyabilmek için İngiliz temsilcilerinden destek isteme talebi ise, onun Sevr'in sorumluluğunu 'dış güçlerin baskısına' dayandırmak suretiyle biraz olsun hafifletebilmek amacını taşıdığı ihtimalini de akla getirmektedir.

Damad Ferid Paşa Sevr'in onaylanması için gerekli ön hazırlıkları yaparken, Sevr'in onaylanması için çabalayan bir hükümete destek vermenin İngiltere için ne gibi faydalar getireceğini izah etmeye özen gösterdi ve dikkatleri Bolşevik tehdidine çekerek, bir anlamda, Milli Mücadele-Bolşevizm yakınlaşmasını İtilaf kanadından yardım koparmak 
için gerekçe olarak kullandı. Yunanlıların 1920 yazında Batı Anadolu'daki ilerlemeleri bile, Damad Ferid Paşa için 'amaca ulaşmak için kullanılacak' bir diğer gerekçeydi. Çünkü Yunanlıların yenilgiye uğrattığı Milli Mücadelecilerin, İstanbul hükümetinin oluşturacağı birlikler tarafından daha kolay bir şekilde yokedilebileceğini düşünüyordu. Kabinesindeki iki bakanın istifasının hemen ardından Ingilizlere sunduğu projesinde, üç aylık bir sürede yirmibeş bin kişilik bir kuvvet hazırlaması için gerekli olan yaklaşık yirmibin sterlinlik borç talebi yer aldı. Bu talep üzerine İstanbul'daki Ingiliz Yüksek Komiseri Amiral Robeck, oluşturulması önerilen askerî gücün "Milli Mücadelecileri bastırıp bastıramayacağı, istenilen paranın yeterli olup olmadığı ve oluşturulacak askerî gücün daha sonradan Milli Mücadelecilere katılma ihtimalinin olup olmadığı" hususunda, Karadeniz Ordusu Kumandanı General Wilson'dan görüş istedi. Wilson cevabında, "önerilen askerî gücün hazırlanmasının en az 6 ay alacağını ve -Bolşeviklerin Milli Mücadelecilere büyük bir destek vermemeleri şartıyla- Anadolu'daki isyancı oluşum karşısında başarılı olabileceğini iletti. Ancak, Londra'daki dışişleri uzmanlarının görüşleri daha çok 'endişe motifleri' taşımaktaydı. Dışişleri Bakanlığı uzmanlarından W.S.Edmonds'a göre asıl sorun, kimlerin Milli Mücadele tarafına katılacağından ziyade, Milli Mücadele yanlısı bir hükümetin İstanbul'da işbaşına gelmesi halinde oluşturulmasına izin verilecek bu askerî gücün Îtilaf çıkarlarına aykırı bir şekilde kullanılması riskinin olup olmadığıydı. D.G.Osbourne, her ne kadar İstanbul hükümetinin oluşturacağı iyi donanımlı bir askerî gücün Milliyetçiler üzerinde etkili olabileceğini düşünmekte ise de, Doğu Anadolu'daki iller söz konusu olduğunda durumun oldukça karmaşık bir hal alacağından çekinmekteydi. G.H.Fitzmaurice, Sevr'i yürürlüğe koyması için İstanbul hükümetine maddi-manevi destek verilmesi gerektiğini savunan Fransız tezlerine referans vererek, Fransızlarla işbirliği içinde olunmasını önerdi. Ayrıca Fitzmaurice'ye göre, Sevr'in onaylanması için çabalayan İstanbul hükümetine destek verilmesinden Yunanlılar da memnuniyet duyacaklardı. M.Hankey ve J.Tilley ise, konuyla ilgili olarak Yunan başbakanı Eleutherios Venizelos'a danışılmasının gerekliliğini vurguladılar. Öte yandan İngiliz Savaş Bakanlığı (War Office)'na göre, İtilaf kanadı, barış antlaşmasının ruhuna aykırı bir izin demek olsa bile, Damad Ferid Paşa'nın Milli Mücadelecilere karş1 oluşturacağ1 askerî güce destek vermeliydi. Böylece, İstanbul hükümeti gerekeni yapacak ve İtilaf devletlerinin veya Yunanistan'ın askeri güçleri konuya karıştırılmayacak, yıpranmayacaktı. Ancak Savaş Bakanlığı'nın görüşü, böylesine bir girişime Yunanlıların olumlu bakmasının zayıf bir ihtimal olduğu yolundaydi.

Damad Ferid Paşa askerî güç oluşturma önerileriyle İtilaf kanadını zorlarken, riskleri göze alamayan İngilizlerin 1920 yılının sonbaharında 'ılımlı' politikalara daha çok rağbet ettiği ve İngiliz dışişleri uzmanlarının --birkaç istisna dişında-- Anadolu'ya uzlaşma heyeti göndermeyi tercih 
etmeye başladığı görüldü. Örneğin, Venizelos'un çok fazla bir toprak talebinde bulunmaması ve Yunanlıların Milli Mücadelecilere karşı başarı kazanması ihtimalinin yüksek olması şartıyla, Yunan askerî müdahelesinin bazı dezavantajlarına rağmen en iyi çözüm olacağını savunan Osbourne bile, Anadolu'ya gönderilecek bir uzlaşma heyetinin yararlı olabileceğini düşünmeye başladı. Öte yandan, örneğin Tilley, Yunan askeri gücünün Milli Mücadelecilere karşı kullanılmasını savunmaya devam etti. Edmonds'a göre ise, Mustafa Kemal ile uzlaşmaya çalışmak, ona saygınlık kazandıracaktı. Bu nedenle Edmonds, öncelikle İstanbul hükümetinin gücünün artırılması ve böylece saygınlığı artacak olan merkezî hükümetin bu gibi isyancılarla kendi başına ugraşması gerektiğine inanmaktaydı.

1920 Ekimi'nde Milli Mücadelecilerin barışcıl yöntemlerle etkisizleştirilmesini daha az masraflı ve daha az riskli bulan İtilaf devletleri, İstanbul hükümeti tarafından Anadolu'ya bir heyet gönderilmesi gerektiğinde hemfikir oldular. Fakat gönderilecek heyetin yetkileri, niteliği ve gönderilme zamanı konusunda uzlaşma sağlanamadı. İtilaf devletleri bir çıkar yol ararken, Damad Ferid Paşa, Milli Mücadelecilere yönelik politikalarında israr ettiği gibi, Sultan'ın tahtından feragat edebileceği tehdidiyle İtilaf kanadını daha da zor bir duruma soktu. Sorun, sonunda, Anadolu'ya bir uzlaşma heyeti gönderilmesine sıcak bakmayan Damad Ferid Paşa'nın istifasıyla kısmen çözüm buldu. İstanbul'daki Fransız Yüksek Komiseri Defrance'nin -özellikle İngilizlerle olan yakın diyaloğundan ötürü- antipati beslediği Damad Ferid Paşa'nın sadrazamlıktan ayrılmasının ardından, İngiliz-Fransız ilişkilerinde beliren gerginlik azaldığı gibi, Milli Mücadelecileri zor kullanarak yıldırmanın zorluğunu kabullenmiş görünen İngiliz dış politika çevreleri, yeni İstanbul hükümetinin Anadolu ile uzlaşabilecek ılımlı kişilerden oluşmasına da destek verdiler. Böylece politik arenada, Damad Ferid Paşa'nın etkin olarak artık yer almayacağı ancak Ankara'nın daha çok söz sahibi olacağı yeni bir dönemin ilk sinyallerinden biri verilmiş oldu. 